\section{First drought and next a plague of extremely unfriendly bees}

\section{Washington}

THE last opportunity to stop the spread into the United States of the Africanized honey bee - dubbed the "killer" bee by the popular press - appears to have been lost. Hastily conceived plans to halt the bees in Mexico are suffering from a lack of organization and seem doomed to failure.

The result could be devastating for the US bee-keeping industry, with a major impact on the $\$ 20,000$ million annual production of bee-pollinated crops.

Africanized honey bees have been spreading north from Brazil at a rate of 200-300 miles a year since they were accidentally released in a breeding experiment there in 1956. They have now reached southern Mexico.

The bees are the progeny of a cross between the African and the European races of the honey bee, Apis mellifera, intended to create a race of bee ideally suited to tropical honcy production. But European bees have been domesticated for centuries and are mild-tempered and easy to keep. Unfortunately, Africanized bees are very different and defend their hives aggressively. Hives of European bees can be placed out in orchards and fields without threat to passers-by. Africanized bees defend an area within about a quarter mile of their hives and will mount spectacular mass attacks on intruders.

Thirty to forty stings per square inch of exposed skin have commonly been recorded from victims of bees. Many people and animals have died as a result.

Africanized honey bees are also poor honey producers and swarm readily, leaving their hives to set up feral nests. Once in the wild they are highly successful, outcompeting native wild bees and domestic European honey bees in gathering nectar.

As the Africanized honey bees have spread from Brazil, they have interbred with European honey bee populations. But that has failed to dilute out their unfavourable characteristics - most probably because the Africanized bee population grew rapidly in the wild and the populations of domestic bees are small in South and Central America.

The US Department of Agriculture (USDA), working in collaboration with the Mexican Ministry of Agriculture, planned to halt the bees at the Gulf of Tehuantepec, Mexico's narrowest point. The idea was to dilute rapidly the African genes in the population by destroying feral bee nests and flooding the area with European drones. But the funding and organization came too late, and the Africanized bees had already arrived. The defence zone had to be pulled back north, to two coastal lowland corridors either side of the Mexican plateau.

Jose Villa, who is helping to coordinate the efforts of USDA and the Mexican Minister of Agriculture, says he "still maintains hope" that enough European bees will be in place to counteract the dense migration of Africanized bees already occurring a few hundred kilometres to the south. But he says that there are organizational problems and plans to saturate the area with drones are behind schedule. Villa notes that Congress appropriated only a fraction of the funds requested, but says that lack of time is a bigger problem than lack of money.

Norman Gary, professor of entomology at University of California, Davis, thinks there is no longer much chance of stalling the Africanized bees: "It's like fighting a

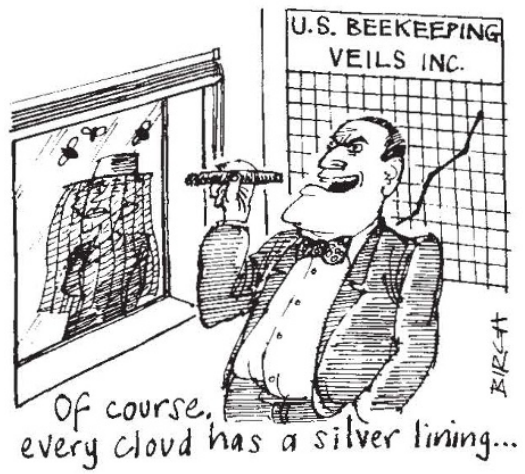

fire, when you are fighting in one area, its spreading in another", he says.

US bee-keepers will face a suite of problems once the Africanized bees arrive Their best hope is continually to re-queen hives whose queens have mated with Africanized drones. But even specialists cannot tell Africanized and European bees apart without a careful microscopic examination. And it will be difficult to maintain a stock of mated replacement queens which are known to have come from unaffected areas.

Litigation may be another problem for the commercial bee industry. Lawsuits are sure to arise if hives containing Africanized bees cause a fatality. Richard Hellmich, a research entomologist at the USDA research service at Baton Rouge, dreads a public outcry, feeling that "legislation and over-reaction may damage the bee industry more than the Africanized bees". Hellmich thinks there may be no way to get rid of the Africanized bees, but that vigilant bee-keepers will be able to cope. He points out that the Venezuelan bee industry collapsed after Africanized bees arrived, but has since managed to recover. "We might have to learn to live with them as we do with cockroaches", Hellmich says.

Alun Anderson
NERC's cuts cost more jobs

\section{London}

THE long-standing financial difficulties of the Natural Environment Research Council (NERC) came to a head last week with the announcement of 130 redundancies to take effect before next April. The research areas to suffer were due to be announced early this week. Marine sciences and terrestrial ecology are to be hardest hit, according to the Institute of Professional Civil Servants (IPCS), which represents public sector researchers. The research station of the Institute of Oceanographic Sciences in Wormley, Surrey, is expected to lose half of its 200 staff; the research station in Wales of the Institute of Terrestrial Ecology could lose around half of its 27 researchers.

NERC has suffered a cash crisis over the past three years because of declining government support. NERC's science budget allocation has declined in real value by $£ 2.5$ million and income from research commissioned by government departments has decreased by $£ 4.5$ million. The increase in commercial income has not compensated for this, so the council was forced earlier this year to cut its support for university research by $£ 2.6$ million and to cancel the grant round for 1988. It has now been allocated $£ 3$ million for shedding staff by the Advisory Board for the Research Councils. The latest staff cuts are part of the trend which saw a reduction of 16 per cent in the staff at NERC between 1983 and 1987.

Meanwhile, financial pressure on Britain's Agricultural and Food Research Council (AFRC) has hit research into animal health. Research at the Institute for Animal Health's laboratories at Compton, Houghton and Pirbright is to be concentrated at the Compton laboratory. Houghton, which carries out research into poultry diseases, is to close, with half the 170 staff fearing redundancy. The rest will be moved to Compton. The situation at Pirbright is still unclear, though research into exotic diseases will continue there.

Since 1983, AFRC has shed around 25 per cent of its workforce, which now stands at almost $5,(000$, and numbers are expected to decrease further next year. Research into animal health has taken an uneven share of the cuts, with a reduction in the institute's staff of 40 per cent to the present 500

Government policy calls for nearmarket work in current public research programmes to be transferred to industry funding. The IPCS fears the government is now looking for large cuts in agricultural research following, a Ministry of Agriculture review of near-market research

Christine McGourty 